\title{
ORIGINALLY ADAPTED MOBILE APPLICATION USED FOR NEUROPSYCHIATRIC PATIENTS
}

\author{
Nada Pop-Jordanova ${ }^{1}$, Sofija Loleska ${ }^{2}$, Mario Loleski ${ }^{3}$ \\ ${ }^{1}$ Macedonian Academy of Sciences and Arts, Skopje, Republic of Macedonia \\ ${ }^{2}$ DF Labs, Skopje, Republic of Macedonia \\ ${ }^{3}$ Ministry of Interior of the Republic of Macedonia
}

Corresponding author: Nada Pop-Jordanova, e-mail popjordanova.nadica@gmail.com

\section{ABSTRACT}

The potential use of modern mobile devices for medical purposes is huge. Digital mental health tools have mostly tended to use psycho-educational strategies based on treatment orientations developed and validated outside digital health.

The aim of this study was to test the availability of our own original app named "Neuro-game" for evaluation of reaction time in different neuropsychiatric patients. Reaction time is strongly related to the executive brain functions.

The examined sample comprised of 135 neuropsychiatric patients (with epilepsy, depres-sion, general anxiety, psychosis and ADHD) compared with matched 50 healthy persons.

We showed that the average reaction time in neuropsychiatric patients compared with healthy people is not notably different. However, we found significant differences in total hits, total misses and total tries in the performances of ill persons.

The crucial differences in obtained scores are confirmed for age and gender issues.

The most important differences are found in the number of hits, misses and tries in the group of depressed, followed by psychotic and ADHD patients, while anxious ones showed pretty normal parameters.

All tested parameters are remarkably different for the epileptic group vs. healthy people.

The T-test for epileptic vs. healthy people showed noteworthy differences for total tries, to-tal misses, and total hits, but the average time reaction did not differ significantly.

In comparison with other psychometric assessments, this approach by using mobile phones seemed more practical, available anywhere (not only in medical settings), less time con-suming and quite interesting for all ages.

Keywords: mobile phones, neuropsychiatric disorders, executive functions, reaction time.

\section{INTRODUCTION}

Digital technology has rapidly and dramatically shifted humans' interaction with the world and presents an enormous opportunity to develop, test, and widely disseminate effective health behavior change interventions. Smartphones have become integrated into most of the human lives.
It is supposed that about 72 percent of Americans and 43 percent of the global population own a smartphone. Our previous study showed that about $98 \%$ of the school population in our country own/use mobile phones. [1] 
Many studies have shown that the overuse of this tool can have a negative im-pact on posture, eyesight, and hearing, distract especially drivers and pedestri-ans leading to higher rates of car disasters. We showed, additionally, that some hypersensitive reaction due to mobile phones uses should not be neglected. [2, 3] In similar studies researchers showed that excessive or "maladaptive" use of phones may be leading to greater incidences of depression, anxiety and sleep problems in users. In a study of Zahra Babadi-Akashe et al. (2014) [4] there were pre-sented the negative effects of mobile phones uses in a population of students, leading to real addiction. They pointed out that many mobile phone addicts are people with low self-esteem and poor social relationships.

However, modern mobile phones with some upgraded technical characteristics are current-ly ready to be used as additional helpful tools in medicine, especially in the field of mental health. [5]

The aim of our study is to present results obtained of originally invented android applica-tion, which we named "neurogame", in testing patients with neuropsychiatric problems. [6, 7] The system is constructed for the assessment of the reaction time related to the atten-tion and concentration in examinees. These psychological functions are directly related to the normal functioning of the executive system in frontal brain regions.

\section{SAMPLE AND METHOD}

Our research consisted of two phases: in the first phase we applied "neurogame" in 201 healthy people to obtain some kind of "data base" for parameters related to attention and concentration. Results of this phase are published in [6, 7]. In the second phas, the system was used in the assessment of patients with neuropsychiatric disorders such as: epilepsy, depression, general anxiety, psychosis and ADHD. The samples of evaluated patients com-prised of: (1) 35 subjects with epilepsy, patients at the Neurological Clinic in Skopje, Medical Faculty. Mean age of examinees is $34.87 \pm 16.23$ years, both genders included. The diagno-sis is made following ICD 10 criteria by a specialized neurologist. All examinees obtained regularly antiepileptic drugs (mono or multidrug included), and were free of seizures mini-mum for one year before this testing. (2) 100 patients with some psychiatric disorders, se-lected by chance at the Psychiatric University Clinic in Skopje. The group with depression comprised of 35 patients, mean age $31.38 \pm 16.95$ years; 15 patients with psychosis, mean age $22.16 \pm 72$ years; group of 20 patients with general anxiety, mean age $24.40 \pm 15.79$ years and 30 patients with ADHD mean age 9.8 \pm 3.5 years. Both genders were included. Diagnosis was made by a specialist psychiatrist using the criteria in DMS-IV. (3) The ob-tained results for patients were compared with matched for age healthy people $(\mathrm{N}=50)$, as control.

Prior consent was obtained following the Helsinki declaration (2000).

As it was said previously, our original Android application was used for testing reac-tion time, number of hits, misses and total tries following five levels of the game (very easy, easy, normal, hard and very hard). Every level has duration of $40 \mathrm{sec}$., each next level being more difficult i.e. the ball moves faster. The client must press the start with the left thumb and as fast as he/she can to press the stop with the right thumb not allowing the ball to pass the median circle.

Obtained results for all examinees are presented in tables and figures. The statistics of the parameter's scores are calculated using Statistic package.

\section{RESULTS}

Table 1 shows the age of examinees presented in years, standard deviation and number of tested patients by group.

Table 1. Age and number of all examinees

\begin{tabular}{|lll|}
\hline Age in years & Number & Diagnosis \\
\hline $34.87 \pm 16.23$ & 35 & epilepsy \\
\hline $31.38 \pm 16.95$ & 35 & depression \\
\hline $22.16 \pm 7.72$ & 15 & psychosis \\
\hline $24.40 \pm 15.79$ & 20 & anxiety \\
\hline $9.8 \pm 3.5$ & 30 & adhd \\
\hline & 135 & total \\
\hline $50 \pm 1.0$ & $\mathbf{5 0}$ & healthy \\
\hline
\end{tabular}


Fig. 1 shows mean reaction time in msec. for all examinees. It is clear that the higher scores are obtained by the healthy people, followed by the group with anxiety, epilepsy, and de-pression, while psychotic patients and children with ADHD showed the lowest scores. Still, no statistical significance was obtained for mean reaction time $(\mathrm{t} h)$ results.

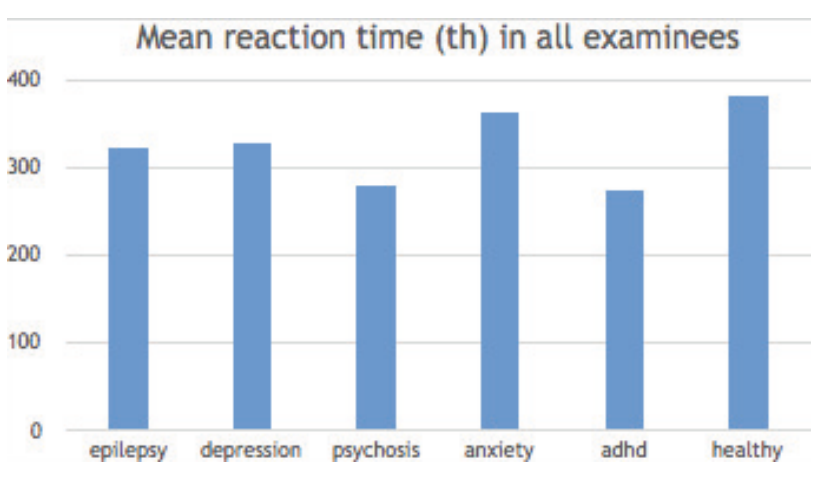

Figure 1. Mean reaction time (in milliseconds) for all examinees

One-way ANOVA calculated for all parameters related to the age and gender showed statis-tical significance $(p<0.001)$ and are presented in Table 2 and 3.

Table 2. ANOVA for gender vs. parameter's scores $\mathrm{tT}=$ total tries; $\mathrm{tH}=$ total hits; $\mathrm{tM}=$ total misses; $\mathrm{th}=$ total time

\begin{tabular}{|c|c|c|c|c|c|}
\hline \multirow[b]{2}{*}{ Effect } & \multicolumn{5}{|c|}{$\begin{array}{l}\text { Univariate Tests of Significance for Gender (Sheet1 in } \\
\text { Sigma-restricted parameterization } \\
\text { Effective hypothesis decomposition }\end{array}$} \\
\hline & SS & $\begin{array}{l}\text { Degr. of } \\
\text { Freedom }\end{array}$ & MS & $\mathrm{F}$ & \begin{tabular}{l|l}
$p$ &
\end{tabular} \\
\hline Intercept & 672261.3 & 1 & 672261.3 & $252098 \mathrm{C}$ & 0.000000 \\
\hline t T & 14.1 & 57 & 0.2 & 1 & 0.604929 \\
\hline Error & 4.0 & 15 & 0.3 & & \\
\hline
\end{tabular}

\begin{tabular}{|l|r|r|r|r|r|}
\hline \multirow{5}{*}{ Effect } & \multicolumn{5}{|l|}{$\begin{array}{l}\text { Univariate Tests of Significance for Gender (Sheet1 in } \\
\text { Sigma-restricted parameterization } \\
\text { Effective hypothesis decomposition }\end{array}$} \\
\cline { 2 - 7 } & $\mathrm{SS}$ & $\begin{array}{r}\text { Degr. of } \\
\text { Freedom }\end{array}$ & MS & $\mathrm{F}$ & $\mathrm{P}$ \\
\hline Intercept & 537889.1 & 1 & 537889.1 & 1753666 & 0.000000 \\
$\mathrm{t} \mathrm{H}$ & 7.7 & 38 & 0.2 & 1 & 0.895733 \\
\hline Error & 10.4 & 34 & 0.3 & & \\
\hline
\end{tabular}

\begin{tabular}{|c|c|c|c|c|c|}
\hline \multirow[b]{2}{*}{ Effect } & \multicolumn{5}{|c|}{$\begin{array}{l}\text { Univariate Tests of Significance for Gender (Sheet1 in } \\
\text { Sigma-restricted parameterization } \\
\text { Effective hypothesis decomposition }\end{array}$} \\
\hline & SS & $\begin{array}{l}\text { Degr. of } \\
\text { Freedom }\end{array}$ & MS & $F$ & $p$ \\
\hline Intercept & 668630.5 & 1 & 668630.5 & 3209426 & 0.000000 \\
\hline t M & 14.7 & 56 & 0.3 & 1 & 0.311136 \\
\hline Error & 3.3 & 16 & 0.2 & & \\
\hline
\end{tabular}

\begin{tabular}{|c|c|c|c|c|c|}
\hline \multirow[b]{2}{*}{ Effect } & \multicolumn{5}{|c|}{$\begin{array}{l}\text { Univariate Tests of Significance for Gender (Sheet1 in } \\
\text { Sigma-restricted parameterization } \\
\text { Effective hypothesis decomposition }\end{array}$} \\
\hline & SS & $\begin{array}{l}\text { Degr. of } \\
\text { Freedom }\end{array}$ & MS & $F$ & $\mathrm{p} \quad$ \\
\hline Intercept & 623990.9 & 1 & 623990.9 & 2634628 & 0.000000 \\
\hline th & 13.6 & 53 & 0.3 & 1 & 0.442062 \\
\hline Error & 4.5 & 19 & 0.2 & & \\
\hline
\end{tabular}

Table 3. ANOVA for age vs parameter's scores $\mathrm{tT}=$ total tries; $\mathrm{tH}=$ total hits; $\mathrm{tM}=$ total misses; th=total time

\begin{tabular}{|l|r|r|r|r|r|}
\hline \multirow{5}{*}{ Effect } & \multicolumn{5}{|l|}{$\begin{array}{l}\text { Univariate Tests of Significance for Age (Sheet1 in Imf } \\
\text { Sigma-restricted parameterization } \\
\text { Effective hypothesis decomposition }\end{array}$} \\
\cline { 2 - 6 } & $\mathrm{SS}$ & $\begin{array}{l}\text { Degr. of } \\
\text { Freedom }\end{array}$ & MS & $\mathrm{F}$ & $\mathrm{p}$ \\
\hline Intercept & 47925.88 & 1 & 47925.88 & 171.0321 & 0.000000 \\
$\mathrm{t} h$ & 12473.93 & 53 & 235.36 & 0.8399 & 0.699746 \\
\hline Error & 5324.10 & 19 & 280.22 & & \\
\hline
\end{tabular}

\begin{tabular}{|c|c|c|c|c|c|}
\hline \multirow[b]{2}{*}{ Effect } & \multicolumn{5}{|c|}{$\begin{array}{l}\text { Univariate Tests of Significance for Age (Sheet1 in Imf } \\
\text { Sigma-restricted parameterization } \\
\text { Effective hypothesis decomposition }\end{array}$} \\
\hline & SS & $\begin{array}{l}\text { Degr. of } \\
\text { Freedom }\end{array}$ & MS & $F$ & $p$ \\
\hline Intercept & 36938.00 & 1 & 36938.00 & 144.3301 & 0.000000 \\
\hline $\mathrm{tH}$ & 9096.50 & 38 & 239.38 & 0.9353 & 0.581260 \\
\hline Error & 8701.53 & 34 & 255.93 & & \\
\hline
\end{tabular}

\begin{tabular}{|c|c|c|c|c|c|}
\hline \multirow[b]{2}{*}{ Effect } & \multicolumn{5}{|c|}{$\begin{array}{l}\text { Univariate Tests of Significance for Age (Sheet1 in Im } \\
\text { Sigma-restricted parameterization } \\
\text { Effective hypothesis decomposition }\end{array}$} \\
\hline & SS & $\begin{array}{l}\text { Degr. of } \\
\text { Freedom }\end{array}$ & MS & $F$ & $p$ \\
\hline Intercept & 54990.33 & 1 & 54990.33 & 195.6154 & 0.000000 \\
\hline t M & 13300.19 & 56 & 237.50 & 0.8449 & 0.690782 \\
\hline Error & 4497.83 & 16 & 281.11 & & \\
\hline
\end{tabular}

\begin{tabular}{|l|r|r|r|r|r|}
\hline \multirow{5}{*}{ Effect } & \multicolumn{5}{|l|}{$\begin{array}{l}\text { Univariate Tests of Significance for Age (Sheet1 in Im/ } \\
\text { Sigma-restricted parameterization } \\
\text { Effective hypothesis decomposition }\end{array}$} \\
\cline { 2 - 7 } & $\mathrm{SS}$ & $\begin{array}{r}\text { Degr. of } \\
\text { Freedom }\end{array}$ & MS & $\mathrm{F}$ & $\mathrm{p}$ \\
\hline Intercept & 57645.22 & 1 & 57645.22 & 288.4825 & 0.000000 \\
\hline $\mathrm{t} \mathrm{T}$ & 14800.69 & 57 & 259.66 & 1.2995 & 0.295813 \\
\hline Error & 2997.33 & 15 & 199.82 & & \\
\hline
\end{tabular}


Correlation between scores obtained by healthy vs. non-healthy examinees is presented in Table 4 and in a scatterplot matrix (Fig. 3).

Table 4. Correlation between obtained scores for healthy vs non-healthy examinees

\begin{tabular}{|c|c|c|c|c|}
\hline \multirow[b]{2}{*}{ Variable } & \multicolumn{4}{|c|}{$\begin{array}{l}\text { Correlations (comparison of healthy vs. non-healthy) } \\
\text { Marked correlations are significant at } p<.05000 \\
\mathrm{~N}=48 \text { (Casewise deletion of missing data) }\end{array}$} \\
\hline & t T (non-healthy) & t H (non-healthy) & t M (non-healthy) & t h (non-healthy) \\
\hline t T (healthy) & -0.30 & -0.34 & -0.20 & -0.48 \\
\hline $\mathrm{t} \mathrm{H}$ (healthy) & -0.30 & -0.30 & -0.22 & -0.40 \\
\hline t M (healthy) & -0.17 & -0.22 & -0.10 & -0.33 \\
\hline th (healthy) & -0.00 & 0.06 & -0.04 & 0.04 \\
\hline
\end{tabular}

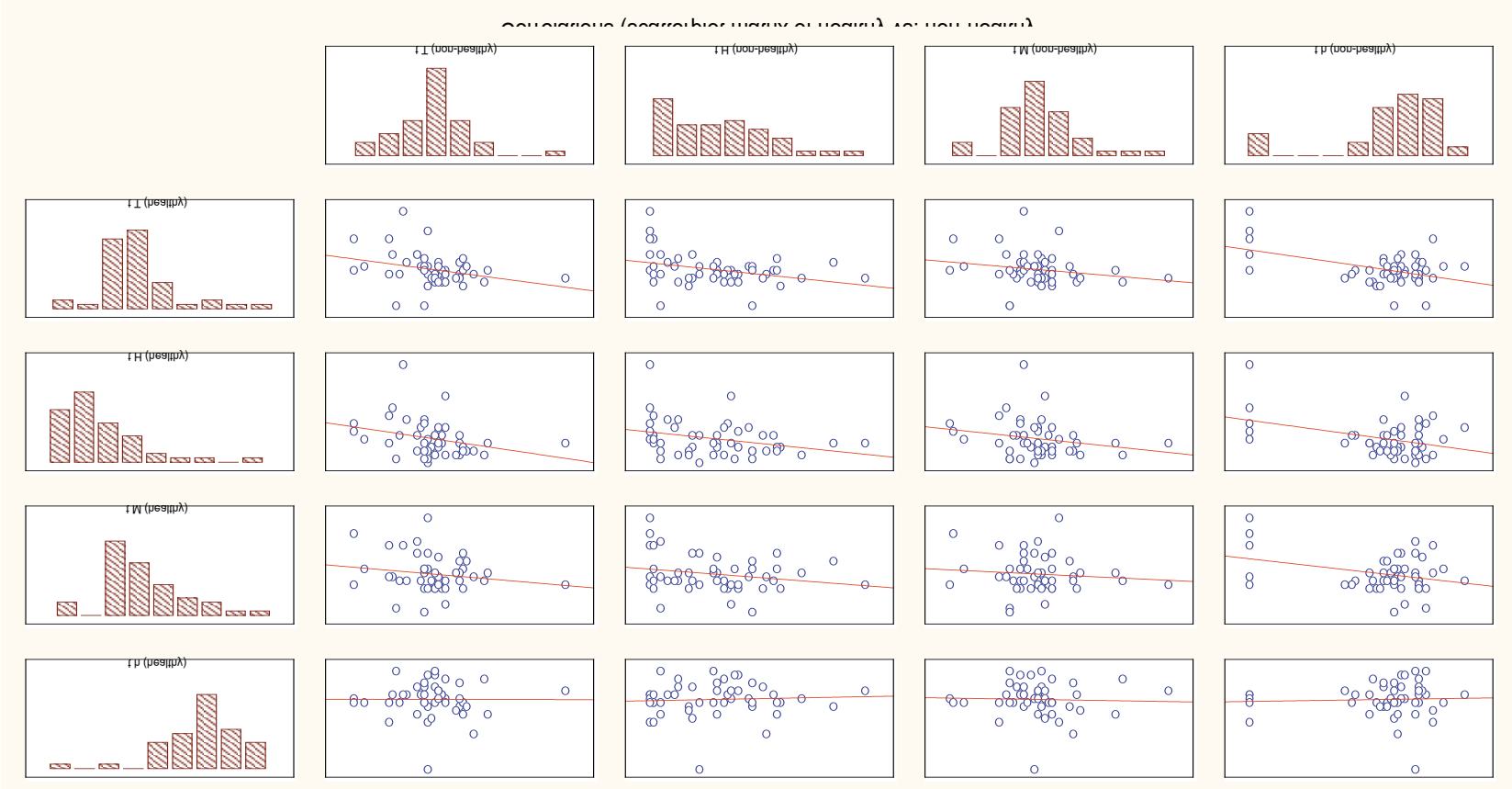

Fig. 3. Scatterplot matrix for scores obtained for healthy vs. non-healthy examinees

Student t-test was calculated for obtained

It is obvious that significant negative correlation is obtained for total hits $(\mathrm{tH})$ and total time (tT), and negative but not significant for total misses (tM) and total time (th) scores. scores in all tested parameters between healthy vs non-healthy examinees (Table 5) and showed significance for $\mathrm{tH}$, tT and $\mathrm{tM}$, but not for th scores. The last is more visible in Fig. 1.

Table 5. Student t-Test between parameters in healthy vs non-healthy examinees

\begin{tabular}{|c|c|c|c|c|c|c|c|c|c|c|c|}
\hline \multirow[b]{2}{*}{ Group 1 vs. Group 2} & \multicolumn{11}{|c|}{$\begin{array}{l}\text { T-test for Independent Samples (healthy vs. non-healthy) } \\
\text { Note: Variables were treated as independent samples }\end{array}$} \\
\hline & $\begin{array}{c}\text { Mean } \\
\text { Group } 1\end{array}$ & $\begin{array}{l}\text { Mean } \\
\text { Group 2 }\end{array}$ & t-value & df & $p$ & $\begin{array}{l}\text { Valid N } \\
\text { Group } 1\end{array}$ & $\begin{array}{l}\text { Valid N } \\
\text { Group } 2\end{array}$ & $\begin{array}{l}\text { Std.Dev. } \\
\text { Group } 1\end{array}$ & $\begin{array}{l}\text { Std.Dev. } \\
\text { Group } 2\end{array}$ & $\begin{array}{c}\text { F-ratio } \\
\text { Variances }\end{array}$ & $\begin{array}{c}\mathrm{p} \\
\text { Variances }\end{array}$ \\
\hline t T (healthy) vs. t T (non-healthy) & 195.4792 & 159.5493 & 2.8153 & 117 & 0.005720 & 48 & 71 & 65.07311 & 70.3793 & 1.16973 & 0.572402 \\
\hline $\mathrm{t} \mathrm{H}$ (healthy) vs. $\mathrm{t} \mathrm{H}$ (non-healthy) & 45.5625 & & 2.3621 & 117 & 0.019821 & 48 & 71 & 36.465 & 8565 & 9691 & \\
\hline $\mathrm{t} \mathrm{M}$ (healthy) vs. t M (non-healthy) & 149.9167 & 128.1690 & 2.1801 & 117 & 0.031256 & 48 & 71 & 50.81331 & 55.0447 & 1.17348 & 0.564405 \\
\hline th (healthy) vs. th (non-healthy) & 346.3750 & 321.9577 & 1.0647 & 117 & 0.289213 & 48 & 71 & 86.90754 & 141.7932 & 2.66192 & 0.000530 \\
\hline
\end{tabular}




\section{DISCUSSION}

Searching the most well-known databases related to health (PubMed, PsycINFO, Cochrane, Scopus, Embase and Web of Science) we can find emerging evidence that mobile phones can play an important role in health care delivery, especially in mental health. Generally, in many published articles devoted to mental health and smartphone, it was shown that text messaging was used in a wide range of mental health situations. Especially, messages are used for managing some problems such as substance abuse, schizophrenia, and affective disorders. In this context, four ways were identified in which text messages were used: re-minders, information, supportive messages, and self-monitoring procedures. Berrouiguet $\mathrm{S}$. et al, (2016) [8] showed that text messaging was especially used in the management of chronic conditions, reactive conditions, and preventative strategies for healthy or at-risk in-dividuals.

Psychoinformatics, a relatively new field in medicine encompasses the cooperation between the disciplines of psychology/psychiatry and computer science in handling large data sets derived from heavily used devices, such as smartphones or online social network sites, in order to enlighten a large number of psychological traits, including personality and mood (Montag et al, 2016). [9] Digital mental health tools have tended to use psychoeduca-tional strategies based on treatment orientations developed and validated outside of digital health.

A pilot study of Mohr et al., (2017) [10] presents a coach-assisted version of a system named "IntelliCare" and evaluates its use and efficacy at reducing symptoms of depression and anxiety. Authors explained "IntelliCare" apps as very interactive, emphasizing the appli-cation of skills through in-app actions, which is different from other known app systems.

Our custom Android application is used for assessing attention, concentration and reaction time in some neuropsychiatric patients: epilepsy, depression, psychosis, general anxiety and ADHD. Reaction time is measured by positive total hits in the 40 second five levels games, using press on the screen of both thumbs of the preferred hand. All examined subjects have diagnosis made in a neuropsychiatric institution following ICD 10 and DMS 4 criteria. All subjects were in remission, but still taking medications. Epileptic patients were free of seizures in the period of one year before the testing.

It is known that attention and concentration are the main functions of the executive brain system. In this context, our Android application indirectly measures the function of the executive system in these patients. In our previous researches, this kind of evaluation we made by QEEG recording, especially by analyses of the ERP's components in the EEG (Pop-Jordanova et al., 2008, 2010; Markovska-Simoska et al., 2011, 2016, 2017). [11-15] However, mobile phone application seems more practical, it is less time consuming, and it is portable and interesting for all examinees.

In the future research, we will ameliorate the system including possibilities to record movements, tremor and other characteristics of some neurological disorders.

\section{CONCLUSION}

Reaction time together with other measured parameters in "neurogame" is strongly related to attention, concentration and depends on the executive function of the brain.

We showed that the average reaction time in a neuropsychiatric patient compared with healthy people is not significantly different. Still, remarkable differences in total hits, total misses and total tries are found in the group of patients compared to healthy people.

Significant differences in obtained scores are confirmed calculating ANOVA for age and gender issues.

The most important differences are found in the number of hits, misses and tries in the group of depressed, followed by psychotic and ADHD patients, while anxious ones showed pretty normal parameters.

All tested parameters are significantly different for the epileptic group vs. healthy people.

T-test for epileptic vs. healthy people showed notable differences for total tries, total miss-es, and total hits, but for average time reaction did not differ significantly.

In comparison with other psychometric assessment, this approach of using mobile phones seemed more practical, available in different 
places (not only in medical settings), less time consuming and very interesting for all ages.

Further research in a similar direction is proposed.

\section{Acknowledgement}

Special thanks to Dr. Mira Polazarevska and Gordana Kiteva-Trencevska for helping us in the selection of patients. This work is partially financed by the project sup-ported by MASA.

\section{REFERENCES}

1. Pop-Jordanova N., Pop-Jordanova S. Health symptoms caused by electromagnetic radiation, Physioacta, 2012; 6 (2): 33-45.

2. Pop-Jordanova N., Loleska S. Hypersensitive reactions in humans due to electromagnetic radiation, Book of digests: 5th Symposium on Applied Electromagnetics - SAEM'2014, Skopje, Macedonia, June 8-11, 2014, eds. L. Petkovska, G. Cvetkovski, Faculty of Electrical Engineering and Information Technologies, Skopje, 2014: 1-2.

3. Pop-Jordanova N., Loleska S. Some negative effects of mobile phone's use, International Journal of Scientific Engineering and Applied Science (IJSEAS), 2015; 2 (6): 2395-3470.

4. Babadi-Akashe Z, Eshrat Zamani B, Abedini Y, Akbari H, Nasim Heday N. The Relationship between Mental Health and Addiction to Mobile Phones among University Students of Shahrekord, Iran. Addict Health. 2014 Summer-Autumn; 6(3-4): 93-99.

5. Pop-Jordanova N, Loleski M, Loleska S. The use of Smartphone in medical practice (Review), Prilozi, Contributions / Macedonian Academy of Sciences and Arts, Section of Biological and Medical Sciences, 2017; No 3: 55-63.

6. Loleski M Loleska S, Pop-Jordanova N. Mobile application "neurogame" for as-sessment the attention, focus and concentration. Contributions. Sec. of Med. Sci., 3, 2017: 9-18.
7. Loleski M, Loleska S, Pop-Jordanova N.Mobile application development for assessment and training. International Journal of Scientific Engineering and Applied Science (IJSEAS). 2017, Vol. 3, issue 10, pp. 1-8.

8. Berrouiguet S, Baca-García E, Brandt S, Walter M, Courtet P. Fundamentals for Future Mobile-Health (mHealth): A Systematic Review of Mobile Phone and Web-Based Text Messaging in Mental Health. J Med Internet Res. 2016 Jun 10;18(6):e135. doi: 10.2196/jmir.5066.

9. Montag C, Duke E, Markowetz A. Toward Psychoinformatics: Computer Science Meets Psychology. Comput Math Methods Med. 2016; 2016: 2983685.

10. Mohr DC, Tomasino KN, Lattie EG, Palac HL, Kwasny MJ, Weingardt K, Karr CJ, Kaiser SM, Rossom RC, Bardsley LR, Caccamo L, StilesShields C, Schueller SM. IntelliCare: An Eclectic, Skills-Based App Suite for the Treatment of Depression and Anxiety. J Med Internet Res. 2017 Jan 5;19(1):e10. doi: 10.2196/jmir.6645.

11. Pop-Jordanova N., Zorcec T., Demerdzieva A., Gucev Z. QEEG characteristics and spectrum weighted frequency for children diagnosed as autistic spectrum disorder, Nonlinear Biomedical Physics, 2010; 4: 4.

12. Pop-Jordanova N. EEG spectra in pediatric research and practice, Contributions. MASA (Sec. Biol. Med. Sci.), 2008; 29 (1): 221-237.

13. Markovska-Simoska S., Pop-Jordanova N., Pop-Jordanov J. Analisis of independent components of cognitive event related potentials in a group of ADHD adults, Contributions. MASA (Sec. Med. Sci.), 2016; 37 (1): [37]-49.

14. Markovska-Simoska, S., Pop-Jordanova N. Quantitative EEG Spectrum-weighted Frequency (Brain Rate) Distribution in Adults with ADHD, CNS Spectrums, 2011, 16 (5): 111-119.

15. Markovska-Simoska S, Pop-Jordanova N. Quantitative EEG in children and adults with atten-tion deficit hyperactivity disorder: comparison of absolute and relative power spectra and the-ta/ beta ratio. Clinical EEG and neuroscience, 2017; 48(1) : 20-32 


\title{
Резиме
}

\section{ОРИГИНАЛНО АДАПТИРАНА МОБИЛНА АПЛИКАЦИЈА КОРИСТЕНА КАЈ НЕВРОПСИХИЈАТРИСКИ БОЛНИ}

\author{
Нада Поп-Јорданова ${ }^{1}$, Софија Лолеска², Марио Лолески ${ }^{3}$ \\ ${ }^{1}$ Македонска академија на науките и уметностите, Скопје, Република Македонија \\ 2 ДФ Лабс, Скопје, Република Македонија \\ ${ }^{3}$ Министерство за внатрешни работи на Република Македонија
}

Потенцијалната употреба на модерните мобилни телефони во медицинската практика е многу широка. Овие дигитални алатки се користат главно во психоедукативните стратегии базирани на терапевтски ориентации, развиени и валидизирани надвор од дигиталното здравје.

Целtа на оваа студија е тестирање на погодноста на сопствената оригинална мобилна апликација, наречена "neurogame" за проценка на времето на реакција кај разни невропсихијатриски пациенти. Времето на реакција е директно зависно од егзекутивните мозочни функции.

Испитуваниот примерок содржи 135 невропсихијатриски пациенти (со епилепсија, депресија, психоза, анксиозност и АДХД), споредени со 50 здрави испитаници, како контролна група.

Покажавме дека средното време на реакција кај невропсихијатриските болни, споредено со здравите луѓе, не е значајно поразлично. Но, постојат значајни разлики во бројот на тотални погодоци, грешки и тоталните обиди при изведбата кај болните.

Потврдени се значајни разлики во резултатите зависно од полот и возраста на испитаниците.

Најголеми разлики се забележуваат во бројот на погодоците, грешките и обидите во групата депресивни, а следуваат психотичните и пациентите со АДХД, додека анксиозните покажаа речиси нормални параметри.

Сите тестирани параметри се значајно различни за епилептичните пациенти вс. здравите луѓe.

Т-тестот за епилептичните наспроти здравите луѓе покажа значајни разлики за тоталните обиди, грешки и погодоци, додека средното време на реакција не е значајно различно.

Во споредба со другите психометриски проценки, овој приод, во кој се користат мобилните телефони, ни се чини попрактичен, пригоден за примена каде било (не само во медицински установи), со помало потребно време, а интересен за сите возрасти.

Клучни зборови: мобилни телефони, невропсихијатриски болни, реакционо време, егзекутивни функции 